\title{
Prescribing Assessment: Are Final Year Medical Students Competent to Prescribe Antibiotics Rationally?
}

\author{
Andrey D. Petrov, Emil Gatchev
}

Medical University of Sofia, Medical Faculty, Department of Clinical Pharmacology and Therapeutics, University Hospital “Tsaritsa Joanna-ISUL”, Sofia, Bulgaria

\section{SUMMARY}

Introduction: The rational use of drugs, especially antibiotics, has been recognized as a serious problem worldwide.

Aim: The purpose of this study was to evaluate the practical skills of Bulgarian medical students in their final year of education to prescribe antibiotics rationally as well as the impact of a training focused specifically on avoiding prescription errors.

Materials/Methods: Medical students from the Medical University of Sofia in their $10^{\text {th }}$ semester of education from two consecutive teaching cycles took part in this study. The students' participation was completely voluntary. The study was performed as academic study after having obtained a positive opinion from the Local Ethics Committee of the University Hospital "Tsaritsa Joanna-ISUL", Medical University of Sofia. The study was planned to be conducted in two separate parts: a pilot study aimed at receiving basic information about the self-assessment confidence of the medical students in prescribing drugs and especially antibiotics rationally and comparing this to their actual prescribing competence and a subsequent pivotal study after having performed a thorough analysis of the results of the pilot study with implementation of the respective corrective measures.

The students' perception of their theoretical knowledge and practical skills to prescribe drugs and especially antibiotics rationally was assessed by means of a questionnaire containing 5 questions whereas their level of antibiotic prescribing competence was assessed by means of solving three simulated patient cases. The appropriateness of written therapeutic prescriptions was assessed independently by two clinical pharmacologists using a three-grade assessment scale: "good", "satisfactory" and "unsatisfactory".

Results: The results of the pilot study showed that $50.35 \%$ of the prescriptions were rated as "good", $21.64 \%$ as "satisfactory" and $28.01 \%$ as "unsatisfactory". The results obtained from the subsequent pivotal study showed that $60.97 \%$ of the prescriptions were rated as "good" (representing a $21.1 \%$ increase), $16.23 \%$ as "satisfactory" (representing a $25 \%$ decrease) and $22.80 \%$ as "unsatisfactory" (representing an $18.6 \%$ decrease). This was accompanied by an increase in the students' self-assessment confidence rated as "good" - from $19.15 \%$ to $34.21 \%$, while "satisfactory" and "unsatisfactory" ratings decreased - from $65.96 \%$ to $55.26 \%$ and from $14.89 \%$ to $10.53 \%$, respectively.

Conclusions: Medical students from the Medical University of Sofia showed a level of competence to prescribe antibiotics rationally commensurable with the level report- 
ed by foreign medical universities. Regardless of the observed discrepancy between the self-assessment rating and the practical antibiotic prescribing skills it was clearly shown that education specifically focused on prescription errors may contribute to the improvement of the students' antibiotic prescribing competence.

Keywords: medical students, prescribing skills, antibacterial drugs

\section{INTRODUCTION}

The World Health Organization (WHO) defined rational use of drugs as patients receiving medications appropriate to their clinical needs, in doses that meet their own individual requirements, for an adequate period of time and at the lowest cost to them and their community [1].

The rational use of drugs, especially antibiotics, has been recognized as a serious problem worldwide [2]. Evidence suggests that newly licensed physicians are not adequately trained to prescribe medications safely $[3,4]$, partly due to lack of adequate pharmacological training during the medical education course [5].

\section{AIM}

The aim of this study was to obtain information about the antibiotic prescribing performance of Bulgarian medical students in their $10^{\text {th }}$ semester of education at the Medical University of Sofia, Bulgaria as well as evaluate the impact of teaching pharmacotherapy specifically focused on avoiding prescription errors.

\section{MATERIALS AND METHODS}

This study was performed as academic study at the Department of Clinical Pharmacology and Therapeutics, Medical University of Sofia. Approval from the Local Ethics Committee of UMHAT “Tsaritsa Yoanna-ISUL", Sofia was obtained before conducting the study. A total of 86 Bulgarian medical students in their $10^{\text {th }}$ semester of education from 2 student cycles in 2018 (a total of three cycles per year), took part on a completely voluntary basis. 48 students took part in the pilot study [6] and 38 students took part in the subsequent pivotal study.

Teaching on clinical pharmacology in both cycles was of mixed form - didactic education and interactive learning, but after performing a thorough analysis of the results obtained from the pilot part, an additional interactive educational seminar on prescribing errors was implemented in the teaching process during the second students cycle.

The students' self-assessment confidence concerning their theoretical knowledge and practical skills in rational drug prescribing was assessed by means of a questionnaire containing 5 multiple choice questions. Their practical skills in rational antibiotic prescribing were then assessed by solving three simulated patient cases by writing appropriate drug prescriptions. Two different sets containing 3 simulated patient cases were randomly distributed among the students. Two of the cases in each set required an antibiotic to be prescribed (either a single drug or a drug combination) and one represented a clinical case where no antibiotics were to be prescribed.

The prescribing competencies of the medical students were assessed independently by two clinical pharmacologists (CPs), taking into account the following criteria:

- Appropriateness of drugs chosen;

- Appropriateness of doses and dosing regimens;

- Conformity of written prescriptions with the accepted prescribing rules in Bulgaria.

According to these 3 criteria the prescribing competencies of the students were rated as:

- Good (all criteria satisfied);

- Satisfactory (minor omissions in one or more criteria);

- Unsatisfactory (major errors in one or more criteria).

The average rating result the two assessing physicians came to was finally taken into consideration.

The students' self-assessment confidence and their prescribing competencies 
assessed by CPs, in both parts of the study, underwent descriptive statistical evaluation. Additionally, the percentage of drugs prescribed by generic name (optimal level: 100\%) was also assessed.

\section{RESULTS}

The results of the previous pilot study revealed an acceptable level (the sum of "good" and "satisfactory' ratings) of competence in antibi-
The thorough analysis of the reasons leading to this suboptimal result revealed 2 major sources of errors:

1. Prescribing antibiotics in cases where they should not have been prescribed (viral diseases or other self-limiting conditions (asymptomatic bacteriuria);

2. Inadequate choice of antibiotics and/or dosing regimens, including:

- inappropriate choice of antibiotics (unnecessary broad-spectrum drugs);

\begin{tabular}{|l|c|c|c|}
\hline \multicolumn{1}{|c|}{ Assessment rating: } & Good: & Satisfactory: & Unsatisfactory: \\
\hline Students self-rating & $19.15 \%$ & $65.96 \%$ & $14.89 \%$ \\
\hline Average assessment by both CPs & $50.35 \%$ & $21.64 \%$ & $28.01 \%$ \\
\hline
\end{tabular}

Table 1. Comparison between the students' self-rating and their practical skills in rational antibiotic prescribing in the pilot study

- inadequate dosing regimens (not conforming to the respective $\mathrm{SmPC}$ );

- oral antimicrobial drugs for patients with hospital-acquired infections; tence (table 1) [6].

otic prescribing in about $71 \%$ of the students as well as a discrepancy between the self-assessment and the actual prescribing compe-

\section{Self-assessment rating:} Good: Satisfactory: Unsatisfactory:

\section{Question 1:}

How would you rate your theoretical knowledge about rational drug prescribing?

\section{Question 2:}

How would you rate your practical skills of rational drug prescribing?

\section{Question 3:}

How would you rate your theoretical knowledge and practical skills of rational antibiotic prescribing?

\section{Question 4: \\ Do you feel confident to prescribe} drugs to real patients?

Overall self-assessment rating:

$$
15 \text { (39.48\%) }
$$

$21(55.26 \%)$

$2(5.26 \%)$

$12(31.58 \%)$

$23(60.53 \%)$

3 (7.89\%)

$13(34.21 \%)$

$21(55.26 \%)$

$16(42.10 \%)$

17 (44.74\%)

5 (13.16\%)

\section{$36.84 \%$}

$53.95 \%$

$9.21 \%$

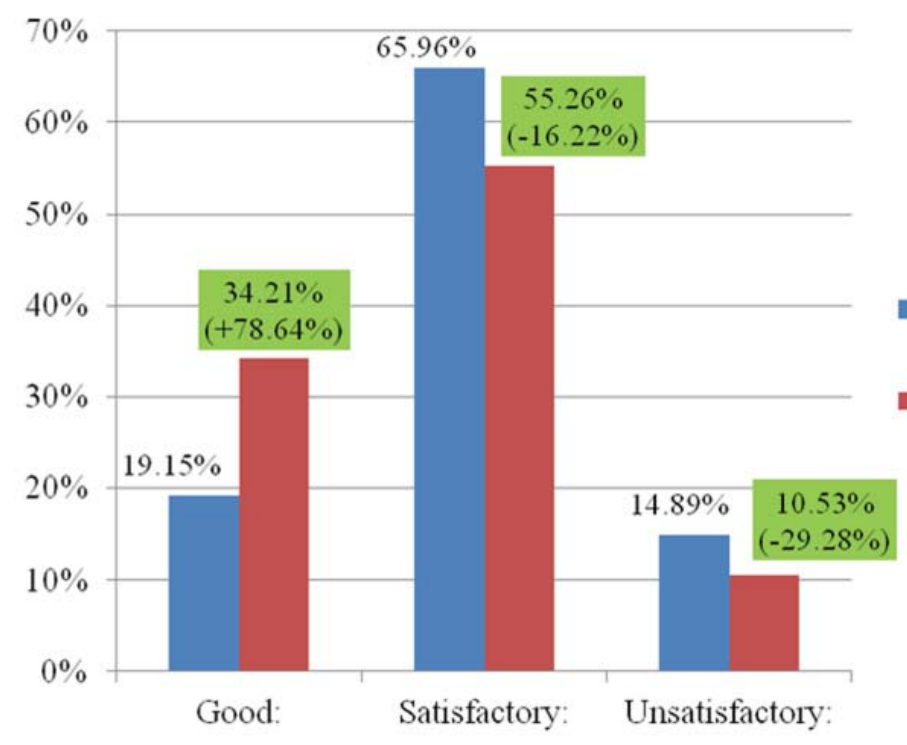

Table 2. Results of the questionnaire about the self-assessed confidence of the medical students concerning rational drug prescribing in the pivotal study (after the $2^{\text {nd }}$ educational cycle)
Figure 1. Comparison of the students self-rating of rational antibiotic prescribing before and after providing education focused on avoiding prescription errors 
Figure 2. Comparison between the students' practical skills in rational antibiotic prescribing in the pilot study (before the additional training) and in the pivotal study (following an intensive training focused on avoiding prescription errors)

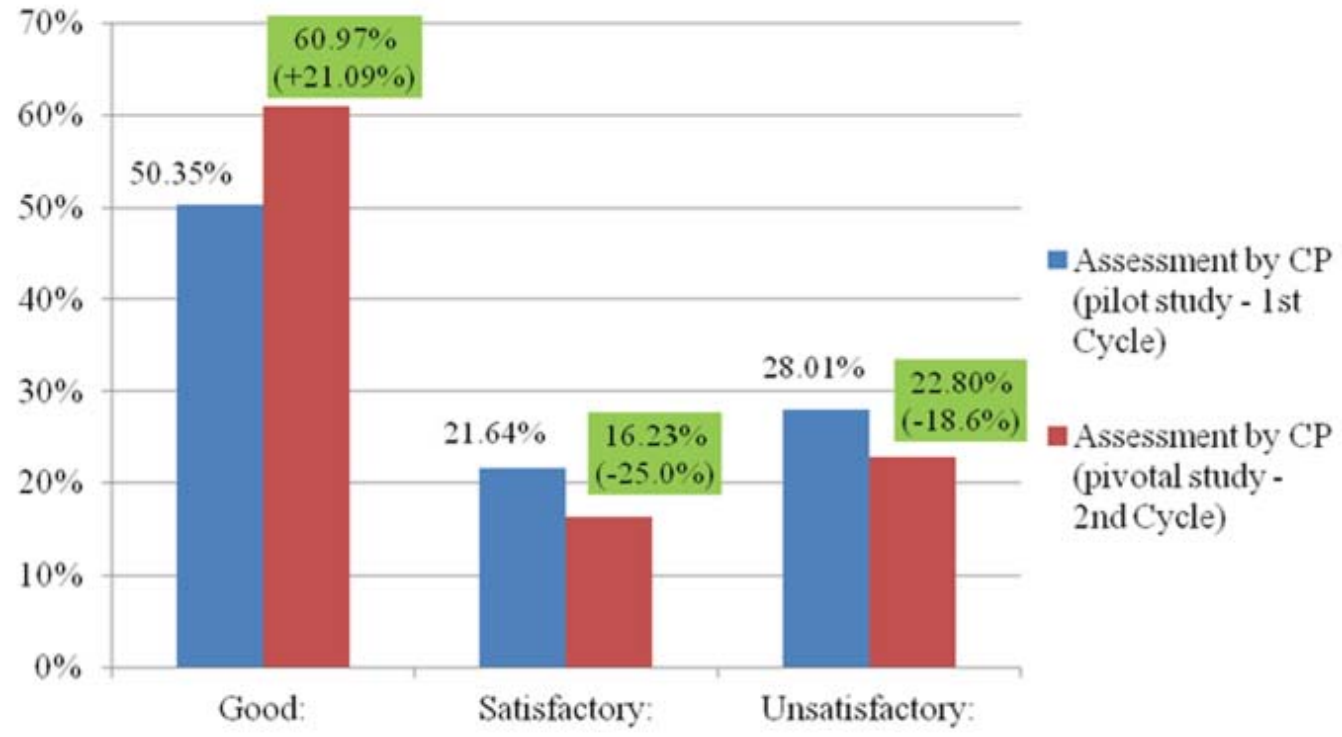

- inadequate duration of treatment (mostly unnecessary long).

In an attempt to improve the antibiotic prescribing skills of the medical students an additional educational seminar on avoiding prescription errors followed by an intensive training in rational antibiotic prescribing in patients with urinary tract infections and pulmonary infections was conducted during the subsequent $\left(2^{\text {nd }}\right)$ student cycle. This additional education led to a $78 \%$ increase in the self-confidence of medical students concerning their theoretical and practical skills to prescribe antibiotics rationally (table 2) as compared to the results of the pilot study.

The fifth self-assessment question was: Education in which discipline at the Medical University of Sofia contributed mostly to your current knowledge about rational drug prescribing?

$81.6 \%$ of all 86 medical students participating in the questionnaire referred to the specialty of Clinical Pharmacology and Therapeutics as the discipline with the most con- tribution to their knowledge about rational drug prescribing followed by Internal Diseases (10.5\%) and Basic Pharmacology (7.9\%).

The additional education provided during the $2^{\text {nd }}$ teaching cycle led to improvement in the students' practical competence for prescribing antibiotics by more than $21 \%$ as presented in figure 2 .

The comparison of the students selfassessment and the assessment by the CPs is presented in table 3 .

There were only minor differences between the assessment ratings of the two CPs concerning the prescribing skills of the students included in the pivotal study as shown in table 4.

The percentage of prescriptions by generic drug names was also determined. In the first cycle these prescriptions amounted to $78.23 \%$ ( 97 out of 124 prescriptions), while in the second cycle $81.93 \%$ of the antibiotics were prescribed by generic names ( 68 out of 83 written prescriptions).
Table 3. Comparison between the students self-rating and their practical skills in rational antibiotic prescribing from the pivotal study

Table 4. Assessment rating by the two CPs concerning the practical skills of medical students in the pivotal study to prescribe antibiotics rationally in three simulated patient cases

\begin{tabular}{|l|c|c|c|}
\hline \multicolumn{1}{|c|}{ Assessment rating: } & Good: & Satisfactory: & Unsatisfactory: \\
\hline Students self-rating & $34.21 \%$ & $55.26 \%$ & $10.53 \%$ \\
\hline Assessment by CPs & $60.97 \%$ & $16.23 \%$ & $22.80 \%$ \\
\hline
\end{tabular}

\begin{tabular}{|l|c|c|c|}
\hline \multicolumn{1}{|c|}{ Assessment rating: } & 1st CP: & 2nd CP: & Average value: \\
\hline Good: & $70(61.40 \%)$ & $69(60.53 \%)$ & $60.97 \%$ \\
\hline Satisfactory: & $17(14.92 \%)$ & $20(17.54 \%)$ & $16.23 \%$ \\
\hline Unsatisfactory: & $27(23.68 \%)$ & $25(21.93 \%)$ & $22.80 \%$ \\
\hline Total: & 114 & 114 & $100 \%$ \\
\hline
\end{tabular}




\section{DISCUSSION}

Irrational prescribing of drugs, especially antibiotics, is wasteful and can be harmful to both the individual and the population. It can lead to increased risk of adverse reactions and unnecessary hospital admissions for individuals. Adverse drug events cause significant morbidity and mortality and rank among the top 10 causes of death in the United States of America. It has been estimated to cost $£ 466$ million annually in the United Kingdom and up to US\$ 5.6 million per hospital per year in the USA [7]. On a population level there is a risk of emergence of antibiotic-resistant strains of bacteria $[8,9,10]$.

Rational antibacterial drug prescribing depends on several factors: antibacterial spectrum, pharmacokinetic characteristics, dose regimen, adverse drug reactions, drug interactions, and cost of treatment. The role of clinical pharmacology units for the application of rational antimicrobial therapy based on these factors, in conformity with current international and local recommendations for rational antibiotic prescribing, as well as for performing routine antibiotic consumption monitoring in clinical centers, has been well established.[11].

Medical students are supposed to have achieved sufficient prescribing competencies at graduation. Surveys all over the world have revealed a widespread lack of confidence in writing prescriptions among medical students [3] and newly licensed physicians $[4,5]$. To the authors' knowledge, at the time of this study only few studies have been performed in Bulgaria measuring the prescribing competency of medical students in their last year of education $[6,12]$.

This study showed a discrepancy between the self-assessed confidence of the medical students concerning their theoretical knowledge and practical skills to prescribe antibiotics and the objective assessment by clinical pharmacologists. The results of the pilot part show that $85 \%$ of the medical students felt more or less confident (the sum of "good" and "satisfactory" ratings) about their personal knowledge and practical skills in rational antibiotic prescribing and about $15 \%$ believed to have insufficient knowledge. In fact, almost $72 \%$ of the medical students showed an acceptable level of knowledge and practical skills (the sum of "good" and "satisfactory" ratings) in rational antibiotic prescribing, whereas $28 \%$ failed to reach an acceptable level. Evaluation of these results revealed 2 main groups of reasons leading to this relatively high percentage of unsatisfactory results during the $1^{\text {st }}$ evaluated student cycle:

1. Prescribing antibiotics in cases where they should not have been prescribed (viral diseases or other self-limiting conditions;

2. Inadequate choice of antibiotics, dosing regimens or duration of treatment.

In the pivotal part of the study performed with the students from the $2^{\text {nd }}$ educational cycle the discrepancy between self-assessment and objective prescribing competences was still present. Almost 89.47\% of the medical students from the $2^{\text {nd }}$ cycle felt more or less confident about their personal knowledge and practical skills in rational antibiotic prescribing and about $10.53 \%$ believed to have insufficient knowledge. The CPs estimated that $77.2 \%$ of the medical students had an acceptable level of knowledge and practical skills in rational antibiotic prescribing, whereas $22.8 \%$ failed to reach an acceptable level. Nevertheless, these results showed clear improvement compared to the $1^{\text {st }}$ educational cycle in both the self-assessment competencies of the students and their practical ability of prescribing antibiotics, showing the impact of conducting a specific training focused on prescription errors. At the same time these results are commensurable to or even better than the results of other studies published $[12,13]$.

Additionally, one of the important WHO/INRUD prescribing indicators [14], namely the percentage of drugs prescribed by generic name was also assessed. WHO highly recommends prescribing medications by generic name as a safety precaution for patients because it identifies drugs clearly and significantly reduces the probability of occurrence of prescription errors [15]. About $82 \%$ of all drugs prescribed by the students who participated in the pivotal part of the study were prescribed by generic names. This represents a slight increase compared to the pilot part and although relatively high it is still below the desired optimal level of $100 \%$. Having in mind that in all but one cases (14 out of 15 cases) with prescriptions by brand names the prescribed drug was Biseptol (INN-co-trimoxazole), for which no generic drug is available in Bulgaria, and only one drug prescribed as a brand name (Zinnat), for which a generic substitute is available on the market, the percentage of generic drug prescribing could be assessed as close to the 
optimal level.

The results of this study clearly show the need to optimize and harmonize the training in clinical pharmacology and therapeutics in Bulgaria as well as in Europe to ensure a uniform high standard of prescribing competency of medical graduates [16].

\section{CONCLUSION}

Medical students from the Medical University of Sofia showed a level of competence to prescribe antibiotics rationally commensurable with the level reported by foreign medical universities. Education specifically focused on prescription errors may contribute to improvement of antibiotic prescribing competence of medical students. Nationwide accepted prescribing competence indicators for medical students should be introduced in order to harmonize the level of prescribing competence at graduation.

\section{LIMITATIONS OF THE STUDY}

A limitation of the study was that it was a relatively small sampled study, including 86 participating medical students from two teaching cycles, representing about $30 \%$ of all medical students of the year 2018 .

\section{ACKNOWLEDGEMENTS}

The authors would like to thank the medical students from the Medical University of Sofia for their participation in this study and their cooperation.

\section{CONFLICT OF INTEREST}

The authors declare that there is no conflict of interest.

\section{REFERENCES}

1. Medicines: rational use of medicines. Fact sheet No. 338. World Health Organization available at: http: //www. who.int/mediacentre/factsheets/ fs338/en/, accessed 16 September 2012.

2. WHO Global Strategy for Containment of Antimicrobial Resistance. World Health Organization 2001, available at: http://www.who.int/drugresistance/WHO_Global_Strategy_English.pdf , accessed 09.10.2018

3. Mucklow J, Bollington L, S. Maxwell S. Assessing prescribing competence. $\mathrm{Br} \mathrm{J}$ Clin Pharmacol. 2011; 74 (4) 632-639.

4. Ryan C, Ross S, Davey P, Duncan E, Francis JJ, Fielding $S$ et al. Prevalence and causes of prescription errors: The Prescribing Outcomes for Trainee Doctors Engaged in Clinical Training (PRO-TECT) Study. PLoS ONE. 2014;9 (1): e 79802

5. Young $\mathrm{H}$. Lack of pharmacological training causes overuse and misuse of drugs. CMAJ. 2007;178 (3):276-76.

6. Petrov A. Skills of Bulgarian medical students to prescribe antibacterial drugs rationally: a pilot study. Journal of IMAB. 2018, Apr-Jun; 24(2), 20202023.

7.Holloway K, Dijk VL. The World Medicines Situation Report 2011. Rational Use of Medicines. World Health Organization; 2011. Available at: http:// www.who.int/medicines/areas/policy/world_medicines_situation/WMS_ch14_wRational.pdf . , accessed 15.10.2018

8.Irrational drug use causing rise of anti-microbial resistance. Geneva, World Health Organization, 2005.

9. Ventola CL. The antibiotic resistance crisis: part 1: causes and threats. P T. 2015 Apr;40(4):277-83.

10. World Health Organization. Antimicrobial Resistance: Global Report on Surveillance;World Health Organization:Geneva, Switzerland, 2014.

11. Kastratović DA, Djukić VB, Majstorović BM, Komrska JJ,Gajić MM, Marković SZ. Antibiotic consumption monitoring at the Institute of Otorhinolaryngology and Maxillofacial Surgery - Clinical Center of Serbia in 2001-2003. Vojnosanit Pregl 2005; 62(7-8): 551-555

12.Bacracheva N, Belcheva A, Gatchev E. Skills of Bulgarian medical students to choose a Rational Drug Therapy. Int J Clin Pharmacol Ther. 2002; 40 (10): 472-473

13. Brinkman DJ, Tichelaar J, Schutte T, Benemei S, Böttiger Y, Chamontin B et al. Essential Competencies in Prescribing: A First European Cross-Sectional Study Among 895 Final-Year Medical Students. Clin Pharm Ther. 2017, 101 (2): 281-289.

14. How to investigate drug use in health facilities: selected drug use indicators. Geneva, World Health Organization, 1993 (EDM).

15.Guidelines on the use of international nonproprietary names (INNs) for pharmaceutical substances. Geneva, World Health Organization, 1997. Available at: htp://apps.who.int/medicinedocs/en/d/ Jh1806e/, accessed 18 September 2018).

16. Brinkman DJ, Tichelaar J, Mokkinkl LB, Christiaens T, Likic R, Maciulaitis R et al. Key Learning Outcomes for Clinical Pharmacology and Therapeutics Education in Europe: A Modified Delphi Study. 2018 Aug; 104(2): 317-325. 


\title{
Procena propisivanja: da li su studenti poslednje godine medicine kompetentni da racionalno propisuju antibiotike?
}

\author{
Andrey D. Petrov, Emil M. Gatchev \\ Medicinski univerzitet Sofija, Odeljenje za kliničku farmakologiju i terapiju, Univerzitetska bolnica “Tsar- \\ itsa Yoanna-ISUL", Sofija, Bugarska
}

\section{KRATAK SADRŽAJ}

Uvod: Racionalna upotreba lekova, posebno antibiotika, predstavlja ozbiljan problem u celom svetu.

Cilj: Svrha ove studije je procena praktičnih sposobnosti bugarskih studenata završne godine medicine da racionalno propisuju antibiotike, kao i uticaj obuke usmerene specifično na izbegavanje grešaka na receptu.

Metod: Studenti medicine Medicinskog univerziteta u Sofiji 10. semestra studija tokom dva uzastopna nastavna ciklusa učestvovali su u ovoj studiji. Studenti su učestvovali u studiji potpuno dobrovoljno. Studija je izvedena kao akademska studija sa dozvolom Etičkog odbora Univerzitetske bolnice "Tsaritsa Yoanna-ISUL”, Sofija, Bugarska. Studija je sprovedena u dva odvojena dela: pilot studija je imala za cilj da se dobiju osnovne informacije o samoproceni znanja studenata medicine o propisivanju lekova, a posebno o racionalnom propisivanju antibiotika; u drugom ključnom delu studije izvršena je detaljna analiza dobijenih rezultata nakon implementacije odgovarajućih korektivnih mera.

Ocjenjivanje percepcije studenata o svom teorijskom znanju i praktičnim veštinama za racionalno propisivanja lekova, posebno antibiotika, procenjeno je pomoću upitnika koji sadrži 5 pitanja, a njihov nivo sposobnosti propisivanja antibiotika ocenjen je rešavanjem tri simulirana slučaja pacijenata. Adekvatnost propisanih lekova ocenila su nezavisno dva klinička farmakologa koristeći trostepenu skalu ocenjivanja: "dobar”, "zadovoljavajući” i “nezadovoljavajući”.

Rezultati: Rezultati pilot studije pokazali su da je 50,35\% propisanih lekova ocenjeno kao "dobro", 21,64\% kao "zadovoljavajuće" i 28,01\% kao "nezadovoljavajuće". Rezultati dobijeni u drugom ključnom delu studije, nakon implementacije korektivnih mera, pokazali su da je 60,97\% propisivanja ocenjeno kao "dobro" (što predstavlja povećanje od 21,1\%), 16,23\% kao "zadovoljavajuće" (što predstavlja smanjenje od $25 \%$ ) i $22,80 \%$ kao "nezadovoljavajuće" ( što predstavlja pad od 18,6\%). Ovo je propraćeno povećanjem pouzdanosti samoocjenjivanja učenika koja je ocenjena kao “dobra" - sa 19,15\% na 34,21\%, dok su "zadovoljavajuća” i “nezadovoljavajuća” ocena smanjena - sa $65,96 \%$ na $55,26 \%$ i sa $14,89 \%$ na $10,53 \%$, redom.

Zaključak: Studenti medicine Medicinskog univerziteta u Sofiji pokazali su nivo kompetencije da propisuju racionalno antibiotike srazmerno nivou koji su objavili strani medicinski univerziteti. Bez obzira na uočene razlike između ocene samoprocene i praktičnih veština za propisivanje antibiotika, jasno je pokazano da obrazovanje specijalno fokusirano na greške na receptu može doprinijeti poboljšanju kompetencije studenata završne godine Medicinskog fakulteta za propisivanje antibiotika.

Ključne reči: studenti medicine, veštine propisivanja, antibakterijski lekovi 